\title{
PREVENTIVE EFFECTS OF PHOENIX DACTYLIFERA POLYPHENOLS AGAINST 7,12-DIMETHYLBENZ(A)ANTHRACENE-INDUCED MAMMARY CANCER
}

\author{
RABAB OMRAN ${ }^{1 *}$, ZAHRAA M AL-TAEE ${ }^{1}$, HAYDER O HASHIM ${ }^{2}$, MOHAMMED J AL-JASSANI ${ }^{3}$
}

${ }^{1}$ Department of Biology, College of Science, University of Babylon, Al-Hillah City, Babel, Iraq. ${ }^{2}$ Department of Clinical Laboratory Sciences, College of Pharmacy, University of Babylon, Babel, Iraq. ${ }^{3}$ Department of DNA Research Center, DNA Research Center, University of Babylon, Babel, Iraq. Email: omranaljelawi@gmail.com

Received: 25 February 2017, Revised and Accepted: 01 April 2017

ABSTRACT

Objectives: Polyphenols are vital micronutrients, in our diet, which have a role in the prevention of progressive cancer and cardiovascular diseases developing. The main objective of this research was to evaluate the chemopreventive effects of some polyphenols of Phoenix dactylifera pits on 7,12-dimethylbenz(a)anthracene (DMBA)-induced mammary cancer of female albino rats.

Methods: The phenolics of $P$. dactylifera pits (Zahidi cultivar) were prepared by successive steps; extraction by ethanol:methanol:HCl: $\mathrm{H}_{2} \mathrm{O}$, adsorption chromatography using a silica gel column and preparative high performers chromatography. The cytotoxic activity of the phenolics was detected against human breast cancer cell line (MCF-7). The acetone phenolic fraction, 50 female albino rats, and DMBA carcinogen were used to study the preventive effects.

Results: The acetone phenolic fraction contained considerable amounts of the total phenolics and having antioxidant activity, which inhibit cancer cell line MCF-7 growth, and the inhibitory concentration $50 \%$ of cells (IC ${ }_{50}$ ) at $24 \mathrm{~h}$ was $202 \mu \mathrm{g} / \mathrm{ml}$ for MCF-7 and $480 \mu \mathrm{g} / \mathrm{ml}$ for WRL-68. The purified phenolic compounds may be related to genistein and quercetin derivatives that inhibited MCF-7 cell line growth and $\mathrm{IC}_{50} \mathrm{were} 1030$ and $203.9 \mu \mathrm{g} / \mathrm{ml}$, respectively, compared with negligible effects on normal cell line. The acetone phenolic fraction prevented mammary cancer formation in the DMBAinduced rat model.

Conclusions: The phenolics of date palm had chemopreventive effects against DMBA-induced mammary cancer, and they required further research to clarify the possible mechanisms that might have contributed to the preventive effects against mammary cancer.

Keywords: Phoenix dactylifera, Polyphenols, Chemopreventive, Mammary cancer

(C) 2017 The Authors. Published by Innovare Academic Sciences Pvt Ltd. This is an open access article under the CC BY license (http://creativecommons. org/licenses/by/4. 0/) DOI: http://dx.doi.org/10.22159/ajpcr.2017.v10i7.18137

\section{INTRODUCTION}

Phoenix dactylifera L., ordinarily well-known as the date palm is a primal plant and has been cultivated for its edible fruit in the Arab world for centuries. $P$. dactylifera belongs to the Arecaceae family [1]; the fruits, pits (seeds) leaves, barks, pollens, and other parts of the tree are rich sources of carbohydrates, protein, amino acids, dietary fibers, phenolics, flavonoids, carotenoids, fatty acids, organic acids and certain vital vitamins and minerals. In addition to its dietary use, the dates are of medicinal applications and are used to treat a range of diseases in the numerous traditional systems of medicine [1-3]. Phytochemical investigations have shown that the fruits contain anthocyanins, phenolics, flavonoids, sterols, carotenoids, and procyanidins compounds known to have multiple valuable effects. Preclinical studies have revealed that the date fruits and pits possess free radical scavenging, antioxidants, antimutagenic, anticancer, anti-inflammatory, antimicrobial, antihyperlipidemic, nephroprotective, gastroprotective, hepatoprotective and immunostimulant activities, and sexual improvement [3-6]

Free radicals are generated by the metabolism of cells, especially in the mitochondria, these molecules are very effective and unstable, so they would cause many human health problems such as cancers and heart diseases. The use of antioxidants can scavenge free radicals directly or indirectly. Plants are a major source of natural antioxidants because they contain phenolic substances as secondary metabolites in plants which contribute to the growth and reproduction of plants $[1,7]$.

Phenolic compounds are present in oil seeds and date fruits, and they are responsible for the dark colors and astringent flavors of some fruits.
Date palm contains significant amounts of phenolic acids, flavonoids, carotenoids, and steroids [8,9]. There are three main families of phenolic compounds in dates, including flavonols, flavan-3-ols, flavan-3,4-diols; proanthocyanidins, and hydroxycinnamates. The hydroxycinnamates are the main group of phenolic compounds and can be found as derivatives of ferulic, synopsis, chlorogenic, and p-coumaric acids as well as their esters such as caffeoyl shikimic acid derivatives [9,10]. Flavonoids such as quercetin, luteolin, proanthocyanidins, and kaempferol are present in fresh dates. These are antioxidants and act as scavengers of free radicals, antimutagens, metal chelators, and signaling agents, and responsible for the protective effects on human health [11-13]. Quercetin has been confirmed to be an excellent antioxidant that can be used as an antiproliferative and anti-inflammatory. Quercetin has been used as a food supplementation, especially for people suffering from hypertension and sarcoidosis disease [14]. Kaempferol has a wide range of pharmacological activities, including antioxidant, anti-inflammatory, anticancer, antimicrobial, antiosteoporotic, antidiabetic, antiallergenic, neuroprotective, cardioprotective, and analgesic activities. It uses cytotoxic effects in numerous types of cancer and helps the body to fight cancer cells [15-17]. Luteolin has been revealed to inhibit tumor cell proliferation and angiogenesis [18].

Mammary cancer is a neoplastic modification in the epithelial cells of the mammary tissue. Most mammary cancers are hormone-dependent mammary cancer that developed depending mainly on the cell hormonal environment $[19,20]$. Estrogen-dependent mammary cancer is initiated when chemical carcinogen molecules such as 7,12-dimethylbenz(a) anthracene (DMBA) bind with the nuclear estrogen receptors [21,22] and then this complex interacts with the cell DNA at the estrogen 
response elements. This reaction induces irreversible change in the cell's genetic which lead to the activation of proto-oncogenes and suppression of tumor suppressor genes that resulting an initiated cell. However, DNA alterations may occur due to the action of other physical or biological carcinogens [23].

In previous our results, the $P$. dactylifera phenolic extract was found the best source of antioxidant in comparing with other studied plant extracts because it had anticancer activity and more effective on breast cancer cell line MCF-7 than normal cell line WRL-68 (unpublished data). Hence, the objectives of this study were investigated the preventive effects of partially purified phenolics of the $P$. dactylifera pits against DMBA-induced mammary cancer.

\section{MATERIALS AND METHODS}

\section{Raw plant material}

In this study, the fruit pits of $P$. dactylifera of Zahdi cultivar was used as a source of phenolic compounds. The authentication of date palm (P. dactylifera) as follows:

Kingdom: Plantae

Phylum: Tracheophyta

Class: Liliopsida

Order: Arecales

Family: Arecaceae

Genus: Phoenix [1-4].

The fruit pits at tamor stage of ripening were collected, cleaned, and dried under the shade at room temperature and then ground and preserved in a clean container at $4^{\circ} \mathrm{C}$ for extraction.

\section{Chemicals}

All solvents, acids and some materials, including methanol $(\mathrm{MeOH})$, ethanol (EtOH), acetone, hexane, ethyacetate, formic acid, glacial acetic acid, dimethyl sulfoxide (DMSO), $\mathrm{HCl}$, silica gel, $\mathrm{Cu}$ (II), ammonium acetate and $\mathrm{Na} 2 \mathrm{CO} 3$ were purchased from Gainland Chemical Co. Ltd., UK. The other materials were purchased from Sigma-Aldrich Co., USA, which including $\mathrm{AlCl} 3$, quercetin, gallic acid, Folin-Ciocalteu reagent, 3-[4, 5-dimethylthiazoyl]-2, 5-diphenyltetrazolium bromide (MTT dye), neocuprine, Trolox and potassium persulfate.

\section{P. dactylifera phenolic extract preparation}

$P$. dactylifera phenolic extract was prepared using the extraction system containing ethanol:methanol: $\mathrm{HCl}: \mathrm{H}_{2} \mathrm{O}$ at a ratio 50:29:1:20. The plant pits of Zahdi cultivar were crushed and milled to produce small particles $(<2 \mathrm{~mm})$. The plant sample $(20 \mathrm{~g})$ was extracted twice with the extraction system $(400 \mathrm{ml})$ at the ratio of raw material to solvent 1:20 by soaking for $24 \mathrm{~h}$ at $30^{\circ} \mathrm{C}$ in shaker incubator (JSSI-200 Series, JSR, Korean). The plant extract was filtered under vacuum, concentrated in a rotary evaporator (IKA HB10, Germany) at $40^{\circ} \mathrm{C}$, and then the concentrated extracts were stored at $-24^{\circ} \mathrm{C}$ for further purification.

\section{Phenolics of $P$. dactylifera purification}

The resulting concentrated crude extract from $P$. dactylifera pits was partially purified using adsorption chromatography by silica gel (mesh 60-120) column. The slurry of silica gel was prepared by soaking with hexane [24-26], subsequently with absolute ethanol and then poured into the column $(25 \mathrm{~cm} \times 2.5 \mathrm{~cm})$ and washed with ethanol for $1 \mathrm{hr}$ to obtain better packing. Concentrated plant extract ( $5 \mathrm{ml}$ ) was loaded into silica gel column and eluted successively with different solvents using batch ways (500 $\mathrm{ml}$ for each) $95 \%$ ethanol, $70 \%$ acetone, $30 \%$ acetone, and deionized water. The solvent was run at $4 \mathrm{ml} / \mathrm{min}$ and $5 \mathrm{ml}$ fraction volume was collected. Frequently, each fraction was checked by absorbance at $275 \mathrm{~nm}$ for phenolic acids and isoflavonoids and $340 \mathrm{~nm}$ for flavonoids and coumestans using a spectrophotometer (PD303 ultraviolet [UV], APEL Co., Ltd., Japan) [24-26]. then estimating phenolic and flavonoid compounds content. Finally, the positive fractions for each solvent were combined together and stored at $-24^{\circ} \mathrm{C}$ for further analysis.
The dried sample of $70 \%$ acetone fraction was further purified by preparative high-performance liquid chromatography (PHPLC). They were dissolved in methanol, filtered through a $0.45 \mu \mathrm{m}$ nylon filter, and injected (2 ml) into the PHPLC system (JASCO-FC2088-30)/Japan, on a $\mathrm{C}_{18}(300 \mathrm{~mm} \times 50 \mathrm{~mm}, 10 \mu \mathrm{m})$ column using mobile phase acetonitrile at a flow rate of $1 \mathrm{ml} / \mathrm{min}$ and with a detection wavelength of $254 \mathrm{~nm}$ [24-26].

\section{Determination of total flavonoids}

The total flavonoids were determined by the method described by Chaves et al. [27]. The extracts were diluted with distilled water to the $2 \mathrm{ml}$ of each test, solution was added the same volume of $2 \%$ $(\mathrm{w} / \mathrm{v}) \mathrm{AlCl}_{3}$ solution in methanol. This mixture remained undisturbed for $10 \mathrm{~min}$ before the ultraviolet (UV) spectrophotometric reading at $415 \mathrm{~nm}$ wavelength. The blank was prepared by replacing $\mathrm{AlCl}_{3}$ solution by methanol. The total flavonoids were determined by the calibration curve using quercetin (Sigma-Aldrich) as standard and expressed in the $\mu \mathrm{g}$ equivalent of quercetin. The results were expressed as micrograms of quercetin $/ \mathrm{ml}$ of the extract.

\section{Total phenolic content}

The Folin-Ciocalteu method was used to determine the total polyphenols, using gallic acid as a standard [27], a $1 \mathrm{ml}$ of diluted test sample was added to $1 \mathrm{ml}$ of $1 \mathrm{~mol} / \mathrm{l}$ Folin-Ciocalteu reagent. This mixture remained undisturbed for $2 \mathrm{~min}$ before the addition of $2 \mathrm{ml}$ of $20 \%$ (w/v) $\mathrm{Na}_{2} \mathrm{CO}_{3}$ solution and left undisturbed for $10 \mathrm{~min}$. After that, the reading was performed by spectrophotometer (optizen pop - Korea) at $757 \mathrm{~nm}$. The total phenolic content was determined by the calibration curve using quercetin gallic acid (Sigma-Aldrich) as standard and expressed in microgram equivalents gallic acid $/ \mathrm{ml}$ of the extract.

\section{Determination of total antioxidant capacity}

Cupric reducing antioxidant capacity (CUPRAC) assay was performed according to the method of Apak et al. [28]. A $0.1 \mathrm{ml}$ each of $10 \mathrm{mmol} / \mathrm{l}$ $\mathrm{Cu}$ (II), $7.5 \mathrm{mmol} / \mathrm{l}$ neocuprine, $1 \mathrm{~mol} / \mathrm{l}$ ammonium acetate buffer (pH 7) solutions, and $0.06 \mathrm{ml}$ water were mixed in a test tube. A 0.05 $\mathrm{ml}$ of diluted tested samples or Trolox standard solutions were added to the initial mixture. The absorbance was measured at $450 \mathrm{~nm}$ after 3-4 min. Trolox standard solutions were prepared at a concentration range from 40 to $400 \mu \mathrm{mol} / \mathrm{l}$.

The total antioxidant capacity was calculated using the following equations:

$\mathrm{An}=\mathrm{At}-\mathrm{Ar}$

$\mathrm{x}=\frac{\mathrm{y}-\mathrm{b}}{\mathrm{m}}$

CRE's value $=x^{*} 2189 \mu \mathrm{mol} / 1$

Where An=Net absorbance read; At=Absorbance of test sample after 3-4 min; Ar=Absorbance of the reference ( $0 \mathrm{~min})$ at $450 \mathrm{~nm}$. The second equation was the standard curve equation of the net absorbance versus Trolox concentration, where: $y=y$-axis value (optical density readings), $\mathrm{m}=$ Slope, $\mathrm{x}$ value coefficient $=\mathrm{x}$-axis value (Trolox concentration $\mu \mathrm{mol} / \mathrm{l}$ ), and $b=$ intercept. CRE's value=Copper reducing equivalents.

The results were expressed as total antioxidant CUPRAC mmol/l.

\section{Cytotoxic activity by MTT assay}

This assay was held at the Centre for Natural Product Research and Drug Discovery, Department of Pharmacology, Faculty of Medicine, University of Malaya/Kuala Lumpur, Malaysia.

To determine the cell viability by colorimetric assay using 3-[4,5-dimethylthiazoyl]-2,5-diphenyltetrazolium bromide (MTT dye), two kinds of cells were employed in this work: The human breast cancer cell line (MCF-7 cell line) and the normal human hepatic cells (non-tumorigenic fetal hepatic cell line WRL-68). Briefly, $100 \mu \mathrm{l}$ 
cell suspension was added onto the flat-bottomed micro-culture plate wells, each line in a separated plate, for the two cell lines and treated them with $100 \mu \mathrm{l}$ partially purified or purified plant extract, incubated for $24 \mathrm{~h}$, centrifuged to remove the dead cells. Aliquot of $100 \mu \mathrm{l}$ from $2 \mathrm{mg} / \mathrm{ml}$ MTT dye was added to each well and incubation was continued for a further $4 \mathrm{~h}$, then $50 \mu \mathrm{l}$ of solubilization solution of DMSO was added into each well. The experiment was performed in triplicate. After complete solubilization of the dye, the absorbance of the colored solution obtained from living cells was read at $620 \mathrm{~nm}$ with an ELISA reader. The mean absorbance for each group of replicates was calculated. The percentage viability of cells exposed to various treatments was obtained as follows $[29,30]$

$$
\% \text { cell viability }=\left(\frac{\text { Mean absorbenace of treated sample }}{\text { Meanabsorbenace of control sample }}\right) \times 100
$$

The control was the nontreated cultures in all experiments that contained cells in the medium only.

\section{Thin layer chromatography (TLC)}

TLC was performed on silica gel G 60-grade absorbent plate, $20 \mathrm{~cm} \times 20 \mathrm{~cm},[24-26]$. Three solvent systems were used separately. The first one $S_{1}=$ Ethylacetate: Acetic acid: Formic acid: $\mathrm{H}_{2} \mathrm{O}$ (100:11:11:26), $\mathrm{S}_{2}=$ Hexane: Ethyl acetate: Glacial acetic acid $(65: 35: 0.5), \mathrm{S}_{3}=$ Ethylacetate: Ethanol: Acetic acid: $\mathrm{H}_{2} \mathrm{O}$ (30:70:0.5:25), and $\mathrm{S}=$ Methanol: Acetic acid: $\mathrm{H}_{2} \mathrm{O}$ at a ratio 40:1:50 (v:v:v). After running, the plates were dried at room temperature. The plates were kept in a TLC chamber containing $5 \%$ of $\mathrm{AlCl}_{3}$ or iodine pellets or ammonium solution $(2 \mathrm{ml})$ and were visualized under visible and UV light for fluorescence. Retention factor $\left(\mathrm{R}_{\mathrm{f}}\right)$ was determined using the following equation:

$$
\operatorname{Rf} \text { value }=\left(\begin{array}{l}
\begin{array}{c}
\text { Distancefrom baseline } \\
\text { travelled by solute }
\end{array} \\
\begin{array}{l}
\text { Distance from baseline travelled } \\
\text { by solvent (solvent front) }
\end{array}
\end{array}\right)
$$

\section{Spectroscopic characteristics}

\section{UV light spectra measurement}

Small amount of the purified phenolic compound was dissolved in methanol, and the spectroscopy characteristic was determined at a range 200-800 nm using Shimadzu UV-visible (UV-VIS) spectrophotometer 1601 (Chemistry Department, University of Babylon).

\section{Infrared (IR) spectra measurement}

This analysis was performed at Chemistry Department, University of Al-Mostansiria. The IR spectrum of the purified phenolic compounds was measured by Perkin Elmer 2000 Fourier transform infrared (FTIR) uses a $\mathrm{KBr}$ discs technique in a range 600-4000/cm [24].

\section{Animal experiments}

\section{Preparation of plant sample}

The partially purified plant extract (500 mg) was dissolved $1 \mathrm{ml}$ ethanol and then completed to $50 \mathrm{ml}$ with distilled water at room temperature and was stored in the refrigerator until use.

\section{Preparation of carcinogen}

A carcinogen DMBA (Sigma-Aldrich, Germany) was freshly prepared at concentration $100 \mathrm{mg} / \mathrm{kg}$ body weight (BW) with a single dose of $20 \mathrm{mg}$ of DMBA diluted in soy oil $(2 \mathrm{ml})$ given the intragastrically by gavage method as described by Alfredo et al. [31].

\section{Tumor induction}

\section{Animals}

Female Wister albino rats $(200 \pm 25 \mathrm{~g})$ of $13 \pm 1 \mathrm{w}$ age were selected for this study. They were obtained from the Animal House at University of Babylon, Iraq. The animals were bred under ideal conditions of temperature $\left(26-29^{\circ} \mathrm{C}\right)$, humidity, and light, and they were fed with free access of water and food (pellets). All animals were housed in a controlled environment in steel mesh cages of six rats each on woodchip bedding, for one week as an acclimatization period. Anesthetic procedures and handling of animals complied with the ethical guidelines of the Medical Ethical Committee of National Research Centre in Iraq, providing that the animals did not suffer at any stage of the experiment.

\section{Experimental design}

A total of 40 female albino rats were selected for this study and divided into five groups (10 rats each) (Table 1). Group 1: Normal, healthy control rats and Group 2: Considered as carcinogen reference which only received the carcinogen as a single dose of $20 \mathrm{mg}$ of DMBA diluted in soy oil $(2 \mathrm{ml})$ given the intragastrically by the gavage method as described by Alfredo et al. [31] to induced tumor and this group was left without any treatment. Group 3 was considered as the test group, each animal received a single dose of $20 \mathrm{mg}$ of DMBA/rat given the intragastrically by the gavage method, after $15 \mathrm{~d}$ the animal orally administered $1.25 \mathrm{mg} / \mathrm{kg}$ BW (Body Weight) of partially purified phenolic extract of P. dactylifera pits (PDE) every $3 \mathrm{~d}$ for $104 \mathrm{~d}$. Group 4 was considered as a drug reference for partially purified plant extract. It was normal rats and orally treated with $1.25 \mathrm{mg} / \mathrm{kg} \mathrm{BW}$ of partially purified extract of $P$. dactylifera pits every $3 \mathrm{~d}$ for $120 \mathrm{~d}$, according to $\mathrm{LD}_{50}$ which reveal the partial purified extract is safe till $2.5 \mathrm{mg} / \mathrm{kg} \mathrm{BW}$. All the animals of groups had free access to food and water.

We performed physical examinations, weekly. Each rat had six pairs of mammary glands that were checked by inspection, touching, and palpation.

For evaluation of the induction pattern, we performed two specific analyses at 8 and $13 \mathrm{w}$ after drug ingestion. At the age of $211 \pm 7 \mathrm{~d}$ (15-17 w after DMBA), the animals were anesthetized with diethyl ether, and then the blood was collected by puncture of the heart and transferred to two clean and dry test tubes, one of them containing anticoagulant to prevent blood clotting and was used to examine blood parameters, the second tube left $10 \mathrm{~min}$ to clot and centrifuged at 3000 revolutions per minute (rpm) for serum separation. The separated serum was used for biochemical analysis of antioxidant analysis.

After the animals sacrificed, complete autopsies were performed, tumor, livers, kidneys, spleens, stomach, and intestines were collected. The mammary tumors were measured and weighed, and the findings recorded. The organs and tumors were divided into two portions. Representative fragments of the tumors and other organs (the first portion) were fixed at $10 \%$ buffered formalin in labeled containers. Tissues were processed routinely and embedded in paraffin wax. Sections of $5 \mu$ thickness were cut, stained with hematoxylin-eosin (H\&E) and examined under the light microscope [32].

The second portion of the tumor and organs was stored at $-24^{\circ} \mathrm{C}$ for further analysis. As well as a portion of livers was weighed and homogenized in 5-10 volumes of bidistilled water by a ratio $1: 10 \mathrm{w} / \mathrm{v}$ using electrical homogenizer, centrifuged at $4000 \mathrm{rpm}$ for $15 \mathrm{~min}$, the supernatants were collected, and placed in Eppendorf tubes, and stored at $-20^{\circ} \mathrm{C}$ and used for determination of total antioxidant status of liver and serum. The homogenization was carried out as described by Newsholme [33]. The total antioxidant status was assayed in the liver tissue homogenate and serum $[8,34]$.

\section{Statistical analyses}

Data were analyzed using SPSS version 22 software Fisher's exact with a significant $p<0.05$.

\section{RESULTS AND DISCUSSION}

The total phenolic compounds were extracted from P. dactylifera pits of Zahdi cultivar using organic solvent system, and results revealed that 
Table 1: Animal experimental design of induction tumor and treatment in rat model

\begin{tabular}{|c|c|c|c|}
\hline \multirow[t]{2}{*}{ Groups (10 rats/group; $B W=200 \pm 25$ g) } & \multirow{2}{*}{$\begin{array}{l}\text { Interval } \\
\text { periods }(d)\end{array}$} & \multicolumn{2}{|l|}{ Treatment } \\
\hline & & $\begin{array}{l}\text { Partially purified phenolics } \\
\text { extract*0.25 mg/rat }\end{array}$ & $\begin{array}{l}\text { Carcinogen (DMBA) } \\
20 \mathrm{mg} / \mathrm{rat}\end{array}$ \\
\hline G : Control & $1^{\text {st }}-120^{\text {th }}$ & - & - \\
\hline G2: Carcinogen reference (DMBA) & $1^{\text {st }}$ & - & Single dose \\
\hline G3: Test (DMBA+PDE) & $\begin{array}{l}1^{\text {st }}-120^{\text {th }} \\
16^{\text {th }}-120^{\text {th }}\end{array}$ & - & Single dose \\
\hline G4: Drug reference (PDE) & $1^{\text {st }}-120^{\text {th }}$ & $\begin{array}{l}\text { One dose } / 3 \mathrm{~d} \\
\text { One dose } / 3 \mathrm{~d}\end{array}$ & - \\
\hline
\end{tabular}

one gram dry weight (DW) of P. dactylifera pits powder gave $12-13 \%$ dry extract which contains $49.75 \pm 0.05 \mathrm{mg}$ gallic acid equivalent (GAE) $/ \mathrm{g}$ DW and $13.71 \pm 0.01 \mathrm{mg} \mathrm{QE} / \mathrm{g}$ DW of the total phenolic compounds and flavonoids, respectively. The total antioxidant capacity of the extract depending on the CUPRAC assay was $6.60 \pm 0.02 \mathrm{mmol} / \mathrm{l}$.

The fruits and pits of the date palm have been considered as a rich source of phenolic contents and correlated significantly with antioxidant activity. The total phenolic contents and antioxidant activities were variable depending on cultivars of dates because they can be affected by numerous factors such as growing conditions, geographic origin, cultivar, maturity of the tested dates and its pits, soil type, season, fertilizers, sampling, extraction method and conditions of storage $[13,35-37,38]$, in addition to the type, structure and conformation of phenolic compounds [39]. Hence, our results of Zahidi cultirvar were in agreement or different with other previous studies, which revealed that the phenolic compounds of three native sun-dried date varieties from Oman (Mabseeli, Shahal, and Um-Sellah) and found; they have total phenolic compounds ranging from 3102 to $4430 \mathrm{mg}$ GAE per $100 \mathrm{~g}$ fresh weight [40]. Another study was reported the phenolic acid composition in the pits of Mabseeli variety which contains p-hydroxybenzoic, protocatechuic, m-coumaric, ferulic, p-coumaric, vanillic, o-coumaric, gallic, and caffeic as the main phenolic acids with concentrations of $9.89,8.84,8.42,6.93,6.07,4.07,3.96,0.28$, and $0.18 \mathrm{mg}$ of galic acid per $100 \mathrm{~g}$ fresh weight, respectively [40]. Furthermore, the phenolic contents of two date varieties, Deglet Nour and Medjol, were 661 and $572 \mathrm{mg}$ of gallic acid per $100 \mathrm{~g}$ fresh weight, respectively [41]. Whereas, the phenolic contents of date were diverse depending on the sample types (part of the plants) such as fruits, seeds, fresh or dried date fruits, such as the comparative studies of Al-Farsi et al. [42] which performed on fresh and three dried date cultivars grown in Oman (Fard, Khasab and Khalas), and they revealed that the phenolic contents ranged from 134 to $280 \mathrm{mg}$ ferulic acid equivalents per $100 \mathrm{~g}$ fresh weight. In comparison with the other studies that measured the phenolic contents of fresh dates of four cultivars (Allig, Deglet Nour, Kentichi, and Khouet Kenta) and found phenolic contents ranged from 209.4 to $447.7 \mathrm{mg}$ GAEs per $100 \mathrm{~g}$ fresh weight [43].

The results of partial purification of $P$. dactylifera pits extract by adsorption chromatography using a silica gel column revealed that all used solvent fractions, including 95\% ethanol, $70 \%$ acetone. $30 \%$ acetone and distilled water could be eluted the phenolic compounds at a percentage $4.81 \%, 12.32 \%, 2.23 \%$, and $58 \%$, respectively, whereas the total flavonoids were soluble only in organic solvents but not in distilled water, and they were eluted at a percentage $1.06 \%, 67.08 \%$ and $8.63 \%$ in $95 \%$ ethanol, $70 \%$ acetone and $30 \%$ acetone, respectively, in other word, the most of the phenolic contents of P. dactylifera was eluted by distilled water (soluble in water) and the most flavonoid content was eluted by $70 \%$ acetone. The partially purified of $P$. dactylifera extract contained $150 \mathrm{mg} \mathrm{GAE} / \mathrm{g}$ DW of the total phenolics; the total flavonoids was $10.5 \mathrm{mg} \mathrm{QE} / \mathrm{g}$ DW and the total antioxidant capacity $5.84 \pm 0.03$ $\mathrm{mmol} / \mathrm{l}$. The $70 \%$ acetone fraction of phenolics was selected to further purification by preparative HPLC-UV (K-2501 UV detector). The best separation conditions were gained using the mobile phase acetonitrile at a flow rate of $1.0 \mathrm{ml} / \mathrm{min}$ and with a detection wavelength of $254 \mathrm{~nm}$.
36 peaks appeared at a retention time ranged from 0.262 to $54.694 \mathrm{~min}$ with total area 38944673 (Fig. 1), out of these peaks only two peaks (8 and 9) which appeared at a retention time 5.637 and $6.702 \mathrm{~min}$ had area 4718475 and 34165367 with height 120410 and 699606, respectively. That indicates the most phenolics of the partially purified acetone fraction composed of two compounds and others were traces. The two peaks ( 8 and 9) were selected to assay the cytotoxic activity against two cell lines (MCF-7 and WRL-68).

Our results were in agreement with previous studies that purified the phenolic compounds by adsorption chromatography using a silica gel column and HPLC techniques $[25,26,44]$. There are many techniques for phenolics purification depending on the type of these compounds and their chemical structures. In our study, we focus on phenolic acid and flavonoid compounds of $P$. dactylifera that were hydrophobic phenolics as antioxidants because we search for anticancer substances depending on the references that reported the flavonoid compounds of $P$. dactylifera had anti-inflammatory and anticarcinogenic effects and it decreases the fragility of blood vessels such as rutin (also known as vitamin P) [45-48], quercetin, and other phenolic acids [9] which had a preventive effect against breast cancer [31].

The cytotoxic activity of the $70 \%$ acetone phenolic fraction of P. dactylifera pits (designated PDE) and the purified fractions of peaks 8 and 9 (designated as A and B compounds) were assayed using two cell lines, including breast cancer cell line (MCF-7) and the normal human hepatic cells (non-tumorigenic fetal hepatic cell line WRL-68). The results appeared that PDE had a cytotoxic effect on the cancer cell line MCF-7 and the inhibitory concentration $50 \%$ of cells ( IC $\left._{50}\right)$ at $24 \mathrm{~h}$ was $202 \mu \mathrm{g} / \mathrm{ml}$ (156.91 $\mu \mathrm{g}$ phenolics) for MCF-7 and $480 \mu \mathrm{g} / \mathrm{ml}(372.86 \mu \mathrm{g}$ phenolics) for WRL-68. Whereas, the purified phenolic compound (B) which represents peak 9 (retention time $6.702 \mathrm{~min}$ ) had cytotoxic activity against both cell lines and the $\mathrm{IC}_{50}$ of cell lines MCF-7 and WRL68 equal $203.9 \mu \mathrm{g} / \mathrm{ml}$ and $1141.4 \mu \mathrm{g} / \mathrm{ml}$ respectively (Table 2). While the phenolic compound (A), peak 8 (retention time $5.637 \mathrm{~min}$ ), had low activity against the MCF-7 cell line $\left(\mathrm{IC}_{50}=1030 \mu \mathrm{g} / \mathrm{ml}\right)$ and negligible activity against WRL-68 cell line, that indicated the purified phenolic compound (B) was more active than partially purified phenolics (70\% acetone fraction) which containing two compounds and other impurities which had may be a negative effect on cytotoxic activity on both cell lines. These results were in agreements with Abou-Elella and Mourad [48] showed that $P$. dactylifera seed extract had anticancer activity against Ehrlich ascites carcinoma cells. Furthermore, the date fruit extract had preventive effects against DMBA-induced mammary cancer in rats, and it is related to the effect on the hormone $17-\beta$-estradiol [31]. It can be used against several kinds of tumor and has been found to exhibit a dose dependent anticancer activity $[31,48]$.

As a result the potential purified phenolic (A) and (B) compounds were selected to characterize by TLC as shown in Table 2. The results of the purified phenolic compounds revealed that the $\mathrm{R}_{\mathrm{f}}$ of compound A was 0.82 (bright yellow spot under UV) and the compound $\mathrm{B}$ had $\mathrm{R}_{\mathrm{f}}=0.84$ (bright yellow spot under UV) using mobile phase methanol:acetic acid:water at a ratio 40:1:50 (v:v:v) in comparison with the quercetin which had $\mathrm{R}_{\mathrm{r}}=0.80$. These results consistent with previous studies $[49,50]$. 


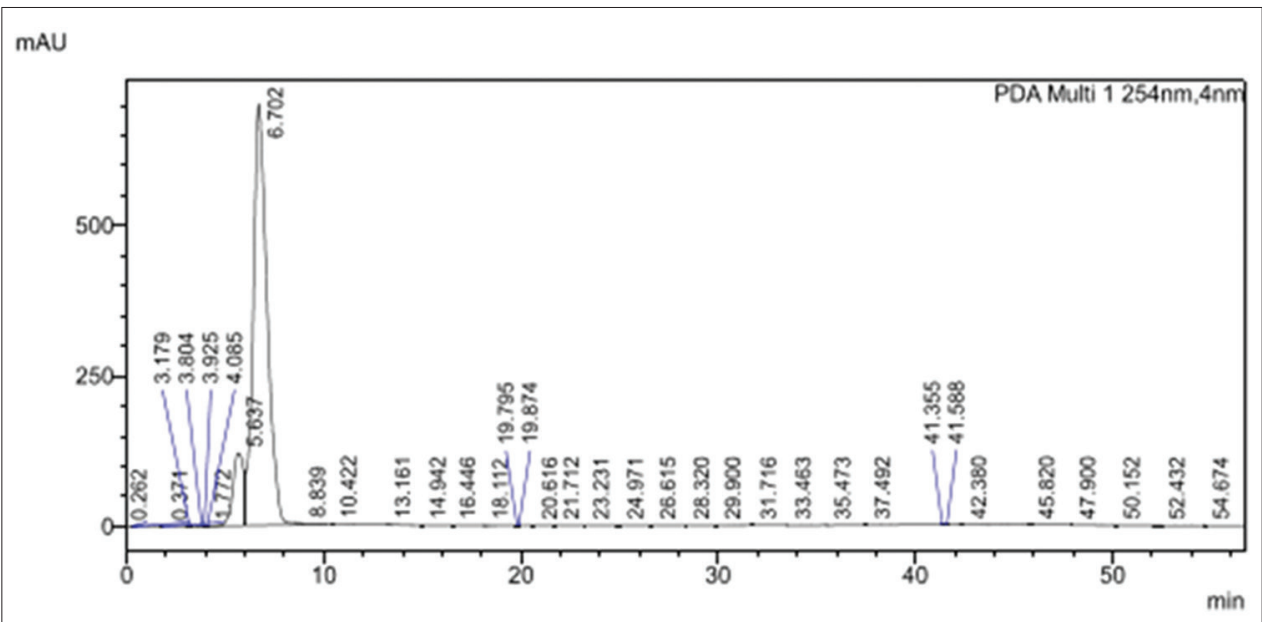

Fig. 1: Preparative high performance liquid chromatography chromatogram of the partially purified of Phoenix dactylifera seeds extract

Table 2: The quantitative and qualitative analysis of purified phenolic fractions of acetone extract of $P$. dactylifera pits

\begin{tabular}{|c|c|c|c|c|c|c|c|c|}
\hline \multirow[t]{2}{*}{$\begin{array}{l}\text { HPLC } \\
\text { peaks }\end{array}$} & \multirow[t]{2}{*}{$\mathbf{R}_{\mathrm{t}}(\mathrm{min})$} & \multicolumn{2}{|c|}{$\begin{array}{l}\text { Cytotoxic activity } \\
\mathrm{IC}_{50}(\mu \mathrm{g} / \mathrm{ml})\end{array}$} & \multirow{2}{*}{$\begin{array}{l}\text { Total } \\
\text { phenolics } \\
(\mu \mathrm{g} \mathrm{GAE} / \mathrm{ml})\end{array}$} & \multirow{2}{*}{$\begin{array}{l}\text { Total } \\
\text { antioxidant } \\
\text { CUPRAC mmol/l }\end{array}$} & \multirow[t]{2}{*}{$\operatorname{TLC}\left(\mathbf{R}_{\mathrm{f}}\right)$} & \multirow[t]{2}{*}{$\lambda_{\max }(\mathrm{nm})$} & \multirow{2}{*}{$\begin{array}{l}\text { Related } \\
\text { phenolic } \\
\text { derivatives }\end{array}$} \\
\hline & & MCF-7 & WRL-68 & & & & & \\
\hline PDE & - & 202 & 480 & $156.91 \pm 0.13$ & $5.84 \pm 0.03$ & 0.82 and 0.84 & 254,300 & Mixture \\
\hline P8 (A) & 5.637 & 1030 & Very wide & $108 \pm 1.24$ & $3.98 \pm 0.15$ & 0.82 & 325 & Genistein \\
\hline P9 (B) & 6.702 & 203.9 & 1141.4 & $102 \pm 0.57$ & $4.21 \pm 0.22$ & 0.84 & 305,370 & Quercetin \\
\hline
\end{tabular}

PDE: 70\% acetone fraction of partially purified extract of $P$. dactylifera pits, R: Retention time, HPLC: High performance liquid chromatography, CUPRAC: Cupric reducing antioxidant capacity, TLC: Thin layer chromatography, P. dactylifera: Phoenix dactylifera, $\mathrm{R}_{\mathrm{f}}$ : Retention factor, GAE: Gallic acid equivalent

The results of the UV/VIS $\lambda_{\max }$ of the compounds, which were dissolved in $95 \%$ ethanol $+\mathrm{AlCl}_{3}+$ potassium acetate, revealed that the compound (A) had a $\lambda_{\max }$ in $235 \mathrm{~nm}, 273 \mathrm{~nm}, 311 \mathrm{~nm}$ and $371 \mathrm{~nm}$, whereas the compound (B) two $\lambda_{\max }$ in $235 \mathrm{~nm}, 274 \mathrm{~nm}, 305 \mathrm{~nm}, 374 \mathrm{~nm}$ and $414 \mathrm{~nm}$. These results consistent with the observance of genistien and quercetin derivatives, which had $\lambda_{\text {max }}$ in 272, 306, $371 \mathrm{~nm}$ for genistein 8-C- $\beta$-Dglucopyranoside and $\lambda_{\max }$ in $274,303,421 \mathrm{~nm}$ for quercetin 3-0- $\beta$-Dglucopyranoside were isolated from date seeds $[43,51,52]$ that may indicate the compounds A and B were genistien and quercetin and their derivatives, where the phenolic acids such as genistin that detected in 213,239 (shoulder), $332-370$ and $\lambda_{\max } 325 \mathrm{~nm}$. Also, chlorogenic (243, $325 \mathrm{~nm}$ ), caffeic; 220, 240 (broad), 294 (pre-shoulder) and $\lambda_{\text {max }}$ $325 \mathrm{~nm}$. Whereas, ferulic was detected in 218, 236 (broad), 294 (preshoulder), $324 \mathrm{~nm}$ and $\lambda_{\text {max }} 325 \mathrm{~nm}$, and sinapic $\left(238,326 \mathrm{~nm}\right.$ and $\lambda_{\text {max }}$ $325 \mathrm{~nm})[9,40,53]$.

Results of FTIR - spectrum of phenolics revealed that the absorption bands of functional and/or structural groups of this spectrum as shown in Fig. 2 and Table 3. The active purified compounds A and B of date pits phenolics presented the bands showed in Fig. 2. It can be observed broad bands for both compounds in a range 3600-3200/cm belongs to stretching vibration of the phenolic hydroxyl group $(-\mathrm{OH})$ which represent to hydrogen bonding [54]. Bands approximately in the same range of wavelength in different phenolic compound were also identified, e.g., a band at $3312.65 / \mathrm{cm}, 3323.61 / \mathrm{cm}$ and $3285 / \mathrm{cm}$, related to stretching $(v)$ vibration of hydroxyl groups $[55,56]$ and a band at $3433 / \mathrm{cm}$, related to $\mathrm{OH}$ wagging $(\mathrm{OH}$ of phenolic compounds) [57]. The band at $2154.49 / \mathrm{cm}$ may be related to $\mathrm{C} \equiv \mathrm{C}$-C of alkynes [56] or may be related to $\mathrm{SH}$ stretch, $\mathrm{CO}$ stretch or $\mathrm{SiH}$ a-stretch [58-60]. Whereas the appearance of two mediums and weak bands at $1625.99 / \mathrm{cm}$ and $1500 / \mathrm{cm}$ stretching vibration of aromatic $(\mathrm{C}=\mathrm{C})$ group. The band at $1625.99 / \mathrm{cm}$ could be due to stretching vibration of $\mathrm{C}=\mathrm{C}$ groups [55], due to aromatic ring deformations [56], due to flavonoids and amino acids: Stretching vibration of $\mathrm{C}=\mathrm{O}$ and of $\mathrm{C}=\mathrm{C}$, asymmetric bending vibration of $\mathrm{N}-\mathrm{H}$ [54], due to $\mathrm{C}=\mathrm{O}$ stretching vibration of caffeic acid and its derivatives $[61,62]$ and/or due to stretching vibration of $\mathrm{C}=0$ of lipids and flavonoids [55,56]. The bands at $1238.3 / \mathrm{cm}$ and $1049.28 / \mathrm{cm}$ would be due to vibration of the C-0 group of hydroxyl flavonoids [56] or related to $\mathrm{C}-\mathrm{OH}$ stretch, $\mathrm{C}-\mathrm{O}$ stretching, $\mathrm{CH}$ deform [57-65].

These compounds had different retention time in HPLC chromatogram and FTIR and UV spectra that indicate these two different compounds may be related to quercetin derivative of the compound B and the compound A related to genistein derivatives due to it was consistent with Pandit and Patravale [65] who studied genistien. Hence, further research will be needed to find out the structural analysis of phenolic compounds ( $A$ and $B$ ) by the use of different analytical methods such as nuclear magnetic resonance and mass spectrophotometer.

\section{Animal experiments}

Breast tissue may be the main goal of the toxic effects of a variety of lipophilic carcinogens such as polycyclic aromatic hydrocarbon (PAH) [65]. DMBA is a member of the PAH family, the metabolic activation of this compound produces radical cations, free radicals, and oxygenated metabolites [66]. Sequentially, the oxidative stress produces harmful effects by initiating lipid peroxidation [67]. In general, therefore, DMBA can induce extensive oxidative damage in various bodily organs (especially liver and breast), a property that has made DMBA an appropriate and useful agent to generate in vivo models of rat breast cancer $[68,69]$. The carcinogenicity of DMBA in rats was accompanied by substantial increases in the activities of antioxidant enzymes, as a response to the induced oxidative stress and production of reactive oxygen species [70]. DMBA produces DNA-reactive species during their metabolism, which may promote oxidative stress in cells. In the cell, the reactive metabolite DMBA-3, 4-dihydrodiol-1,2-epoxide (DMBA-DE) adds adenine and guanine residues in DNA. The conversion of genotoxic metabolites as DMBA-DE is promoted by the action of the cytochrome P450 family. CYP1A1 and CYP1B1 are identified as the enzymes that metabolize DMBA to produce DMBA-DE [71]. Subsequently, it has disrupted vital cellular functions by damaging proteins and lipid membranes. As a result, these changes induced developing leukemia and anemia $[72,73]$. 


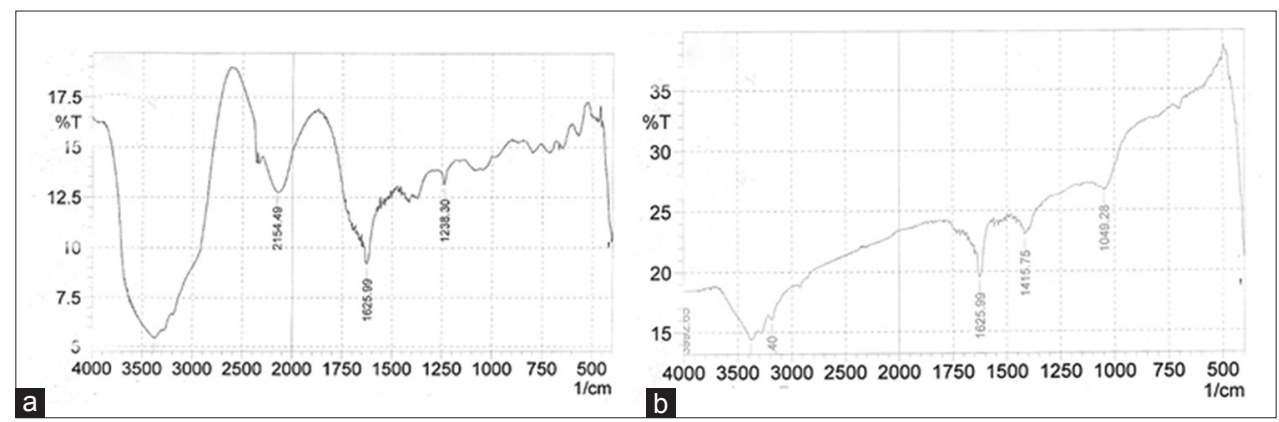

Fig. 2: (a-b) Fourier transform infrared spectra of the purified active fractions of Phoenix dactylifera pits extract The compound (A) contained the peaks: $\mathrm{C}-\mathrm{OH}$ at $1238.30 / \mathrm{cm}$, aromatic $\mathrm{C}=\mathrm{C}$ and $\mathrm{C}=\mathrm{O}$ at $1625.99 / \mathrm{cm}$, Alkyne $\mathrm{C} \equiv \mathrm{C}-\mathrm{C}$ at $2154.49 / \mathrm{cm}$, phenolic $0-\mathrm{H}$ group at 3379.29/cm. The compound (B) contained the peaks: $\mathrm{C}-\mathrm{OH}$ stretch in 1049.28/cm, C-O/C-H bending at $1415.75 / \mathrm{cm}$, aromatic C=C and $\mathrm{C}=\mathrm{O}$ at $1625.99 / \mathrm{cm}$, phenolic $\mathrm{O}-\mathrm{H}$ group at $3381.21 / \mathrm{cm}$ and $\mathrm{O}-\mathrm{H}$ stretch at $3186.40 / \mathrm{cm}$.

Table 3: The functional groups of purified active substances of $P$. dactylifera pits extract determined by FTIR

\begin{tabular}{|c|c|c|c|c|c|}
\hline Peaks & Wavenumber $\left(\mathrm{cm}^{-1}\right)$ & Bond & $\begin{array}{l}\text { Functional } \\
\text { group }\end{array}$ & Group band $\left(\mathrm{cm}^{-1}\right)$ & Reference \\
\hline 1 (B) & 3381.21 & $\mathrm{H}$ - bounded of phenolic $\mathrm{O}-\mathrm{H}$ & & $3600-3200$ & [54-57] \\
\hline $2(\mathrm{~A})$ & 3379.29 & Alcohol/Phenol & & & \\
\hline 3 (B) & 3186.40 & $\mathrm{O}-\mathrm{H}$ stretch & & & \\
\hline \multirow[t]{4}{*}{$4(\mathrm{~A})$} & 2154.49 & $\mathrm{C} \equiv \mathrm{C}-\mathrm{C}$ & Alkyne & $2260-2110$ & [55-60] \\
\hline & & SH stretches & & 2154 & \\
\hline & & CO stretch & & 2153.8 & \\
\hline & & $\mathrm{SiH}$ a-stretch & & 2154 & \\
\hline \multirow[t]{2}{*}{$5(\mathrm{~A} \& \mathrm{~B})$} & 1625.99 & $\mathrm{C}=\mathrm{C}$ stretch & Aromatic & $1675-1600$ & {$[64,60]$} \\
\hline & & $\mathrm{C}=\mathrm{O}$ stretching mode & Ketones & $1675-1625$ & \\
\hline 6 (B) & 1415.75 & $\mathrm{C}-\mathrm{O} / \mathrm{C}-\mathrm{H}$ bending & & $1421-1415$ & [60] \\
\hline \multirow[t]{3}{*}{7 (A) } & 1238.30 & C-OH stretch & Ether & $1300-1000$ & {$[49,55]$} \\
\hline & & $\mathrm{C}-\mathrm{O}$ stretching & Ether & $1275-1200$ & [57-63] \\
\hline & & $\mathrm{CH}$ deform & & 1237.70 & \\
\hline 8 (B) & 1049.28 & $\mathrm{C}-\mathrm{OH}$ stretch & Ether & $1300-1000$ & {$[54,55]$} \\
\hline
\end{tabular}

FTIR: Fourier transform infrared spectra, P. dactylifera: Phoenix dactylifera

In our results, the female rat groups were received the chemical carcinogen DMBA at the age of 91-98 d. After 12-21 w, the animals revealed variable phenotypic characteristics including $50 \%$ of them formed tumors (DMBA-induced mammary tumor), as well as all DMBA-rat tongue converted to the dark-gray to black color and their eyes suffering from bleeding (Fig. 3). The rate of tumor transformation was very low in comparison with the previous studies that documented that the rat groups were received the carcinogenic agent at the age $57 \mathrm{~d}$. Because of the susceptibility of the mammary gland to DMBA carcinogenesis is strongly age-dependent, being maximal when the drug is administered to rats between the ages of 45 and $60 \mathrm{~d}$, which is the age of the beginning of sexual maturity [74].

In the present study, the DMBA-PDE and PDE-reference groups were orally treated with $1.25 \mathrm{mg} / \mathrm{kg}$ BW of partially purified extract of P. dactylifera pits every $3 \mathrm{~d}$ for $120 \mathrm{~d}$; the $\mathrm{LD}_{50}$ PDE was $2.5 \mathrm{mg} / \mathrm{kg} \mathrm{BW}$. In other word, each animal received $0.25 \mathrm{mg}$ of the PDE which containing $37.5 \mu \mathrm{g}$ of total phenolics and $2.6 \mu \mathrm{g}$ of total flavonoids and the $\mathrm{LD}_{50}$ PDE was $75 \mu \mathrm{g}$ of total phenolics and the total antioxidant capacity was $3.41 \pm 0.01 \mathrm{mmol} / \mathrm{l}$.

The survival, ages of rats were different among groups like DMBAreference group was survival for 7-12 w, whereas DMBA-PDE group (test group) was survival for 16-21 $\mathrm{w}$ in comparison with the control and PDE-reference groups were survival until end the experiment $(21 \mathrm{w})$. That may be indicating the partially purified PDE phenolics enhanced rat health and immunity and the rats became more active in comparison with the DMBA - reference group as a result significantly prolongs the lifespan of rats, also the symptoms of bleeding eyes and dark-tongue gradually disappeared after rats treated with PDE phenolics. In addition to the DMBA treated group showed a highly significant decrease $(\mathrm{p}<0.05)$ in $\mathrm{BW}$ gain compared to the control group) as shown in Fig. 4. The obtained results were in agreement with the findings of Mathivadhani et al. [75]. The loss in BW of rat was in agreement with Devlin [76] who reported that the weight loss in the treated rats is largely from skeletal muscles and adipose tissue with relative sparing of visceral proteins. Otherwise, DMBA+PDE treated group displayed a highly significant increase in $\mathrm{BW}$ when compared to DMBA treated group and this may be due to the antioxidant activity of $P$. dactylifera. However, $P$. dactylifera is ranked one of the plants with highest antioxidant values [77].

After sacrificing animals found that many changes in blood parameters and histopathology characteristics of some organs such as the spleen, liver, kidney, and digestive system in comparison with control. In spite of the DMBA exposed rats (DMBA reference group) became very slim, they collected fats in the abdominal cavity and formed tumors ( $50 \%$ rats) in different sizes ranged from 1.2 to $3 \mathrm{~cm}$ with weight ranged 1-3.1 g. The DMBA carcinogen induced different types of tumor, including fat cysts, connective mass tissue and mammary gland carcinoma (Fig. 5). Whereas the other groups had not any tumor, but both DMBA reference group and the DMBA-PDE group suffered from anemia.

As an indication of stress, the use of hematological methods provides valuable knowledge about physiological reactions occurring against changing environmental conditions, particularly understanding the physiological and hematological changes occurring at sublethal toxicity, to expect the possible level of threat to life. In this study, a 


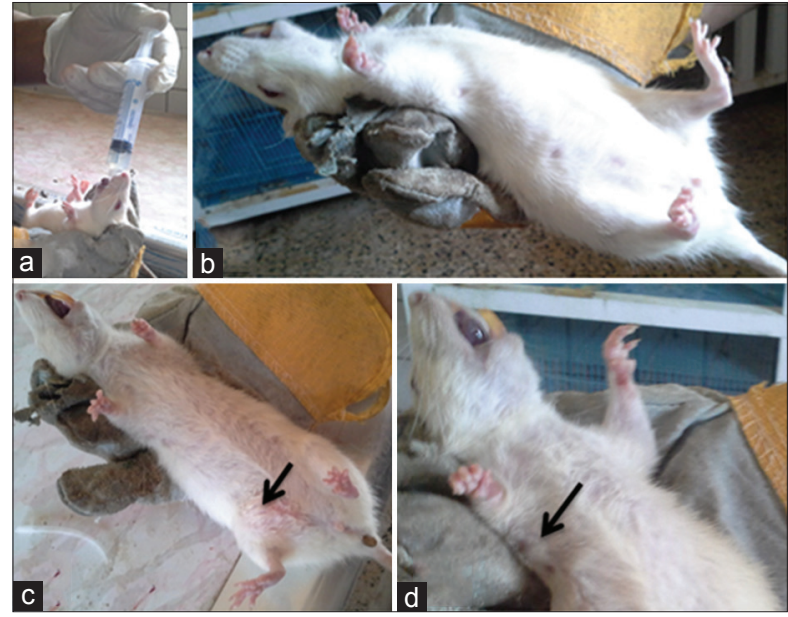

Fig. 3: Animal experiments using Female Wister albino rats $(200 \pm 25 \mathrm{~g})$ of $13 \pm 1 \mathrm{w}$ age treated with DMBA carcinogen and partially purified phenolics agent given the intragastrically by the gavage method (a); control (b); tumor formation with change tongue color to dark-gray to black (c and d)

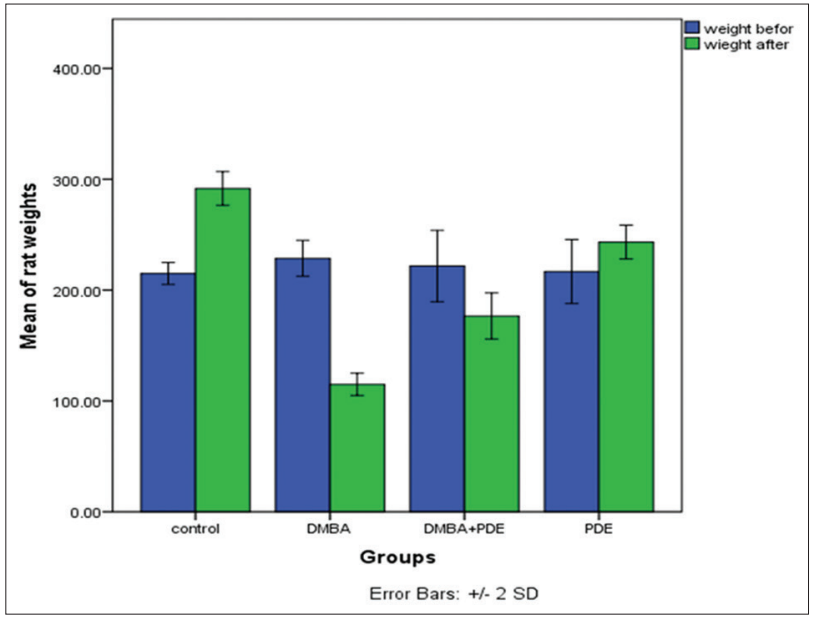

Fig. 4: Rat body weights before and after treatment with carcinogenic agent DMBA and drug partially purified phenolics of date pits

Values are expressed as mean \pm standard deviation (SD) $(n=6)$.

Statistical significance was done by oneway analysis of variance

(ANOVA) followed by least significant difference (LSD). The mean difference is significant at the 0.05 level $(\mathrm{p}<0.001)$ of rat weights after treatments. Dunnett t-tests (2-sided) treat one group as a control, and compare all other groups against it.

statically significant increase $(\mathrm{p}<0.05)$ in total leukocyte count (white blood cells [WBC]), eosinophil, neutrophil, and monocyte values for rats exposed to DMBA as [73] have been observed. However, there was a statistically significant increase in lymphocyte value $(p<0.05)$, and not significant changing basophil value $(\mathrm{p}<0.05)$, as shown in Table 4.

In addition, high leukocyte values depending on DMBA toxicity result from the stimulation property of this toxic and depressive agent on the immune system $[78,79]$. The toxic effect of DMBA caused a stress on the rats. With administration of partially purified PDE-phenolics, the toxic effect of DMBA decreased statistically significantly $(p<0.05)$ (Table 4). Statistically significant decreases in hemoglobin and hematocrit values for rat exposed to DMBA have been shown [73]. However, there was a statistically significant decrease in mean corpuscular volume (MCV) and mean corpuscular hemoglobin ( $\mathrm{MCH}$ ) values, and, in addition, not significantly changing magnesium hydroxy-carbonate hydrate $(\mathrm{MHCH})$ and erythrocyte values $(\mathrm{p}<0.05$ and Table 4$)$. With administration of PGE-phenolics, the toxic effects of DMBA on MCV and MCH values could be prevented significantly ( $<<0.05$ and Table 6). Higher red cell distribution values indicate greater variation in size of erythrocyte, anemia resulting from an inability of the bone marrow to produce red blood cells.

In essence, a decrease in hemoglobin and hematocrit values can be an indicator of anemia, subsequently resulting in inhibition of erythropoiesis in the hemopoietic organism [80], Furthermore, decrease in MCV value showed that anemia was a microcytic anemia monochrome type because there was no change in $\mathrm{MHCH}$ value.

It is known that oxidative stress can change hematological parameters such as erythrocyte number, hemoglobin amount hematocrit value, and total leukocytes.

The blood parameters of rat groups appeared that the groups received carcinogenic agent DMBA suffered from lymphoma, anemia and increasing in platelet numbers (Table 4) which indicated these animals suffering from cancer like leukemia. The rat group received the partially purified phenolics drug after carcinogen, they were becoming more active than DMBA reference group and their blood parameters were enhancing gradually through 4 months that indicated that the drug enhancing animal immunity, also they may be required long time of drug treatment for healing. DMBA carcinogen could not induce tumor in the DMBA-PDE group may be partially purified PDE was stopped the multiplying mammary cells due to prevention effects in comparison with control group DMBA reference because of the partially PDE of date pits are very rich in antioxidants and has the estrogen-like activity that bind to estrogen receptors in mammary cells and prevent DMBA from binding with these receptors [77]. Phenolics and flavonoids such as ginestin and quercetin have protective effects in estrogen-dependent breast cancer by binding to estrogen receptor and modulating estrogen metabolism by selective inhibition of CYP1B1 activities without affecting CYP1A1 or CYP1A2 [81]. Since flavonoids inhibit DNA binding, they have antimutagenic, anticlastogenic, antitumor, and anticarcinogenesis effects [82-85]. The above results were in agreement with previous studied that documented that the DMBA carcinogen induced leukemia in rats by its effects as a mini - nucleus and induces single- and double-strand breaks in nuclear and mitochondrial DNA [72]. In addition to forming DNA adducts, oxidative products resulting from mutagen metabolism, such as DMBA, has disrupted vital cellular functions by damaging proteins and lipid membranes. As a result, these changes induced by the chemical carcinogen DMBA, was reported to be developing leukemia and anemia $[72,73]$.

When the measurement of the total antioxidant status of serum and liver concentrations were estimated of rat groups, the results appeared that the total antioxidant status in serum had no significant variation in comparison with liver that appeared a significant variation $(p<0.05)$ between DMBA and DMBA+PDE groups compared with control group of liver antioxidants (Fig. 6) that indicate the amount of free radicals in liver rats of DMBA reference group were higher than DMBA+PDE group, as a result of inhibiting of antioxidant enzyme activities by DMBA carcinogen, and these results were in agreement with the previous studies $[85,86]$

The total antioxidant status assay is practically measures nonprotein total antioxidant capacity. However, proteins constitute the main antioxidant component of serum (plasma). The randox-total antioxidant status assay can determine the antioxidative effects of bilirubin, vitamin C, uric acid, ascorbic acid, glucose polyphenols, and proteins such as transferrin and albumin, whereas the total antioxidant status assay in the liver is measured protein total antioxidant capacity [87]. The liver is the central organ of metabolism and acts as an organ of storage. Hepatic cells metabolize many 
potentially toxic substances. The greater susceptibility of liver to damage by chemical agents is presumably a consequence of its primary role in the metabolism of foreign substances [88]. The liver is thus a versatile organ involved in drug metabolism and detoxification, hence the antioxidant enzymes and other parameters were estimated in the liver as well as serum. The reduced form of glutathione (GSH) is a biological antioxidant present in high amounts, especially in the liver and its presence is prerequisite for protection against oxidative damage. Decreased levels of GSH accompanied by decreased activities of antioxidant enzymes superoxide dismutase (SOD), glutathione S-transferase (GST), catalase, and glutathione reductase (GR) show the poor antioxidant status of rats treated with either stress or DMBA alone or in combination. The decreased levels of GSH and GST as observed in restrained rats might help in DMBA-induced carcinogenesis by decreasing its clearance from the system [88]. The extracellular fluids of animals, such as blood plasma and tissue fluid, contain little or no catalase activity and only low activities of SOD. There is also very little reduced GSH in most extracellular fluids-about $20 \mathrm{mM}$ in the plasma of rats. Therefore, the major antioxidants found in blood plasma are ascorbic acid, uric acid and glucose, in addition to transferrin and albumin. Ascorbic acid has multiple antioxidant properties, including an ability to regenerate a-tocopherol by reducing a-tocopheryl radicals on the surface of membranes. Uric acid can

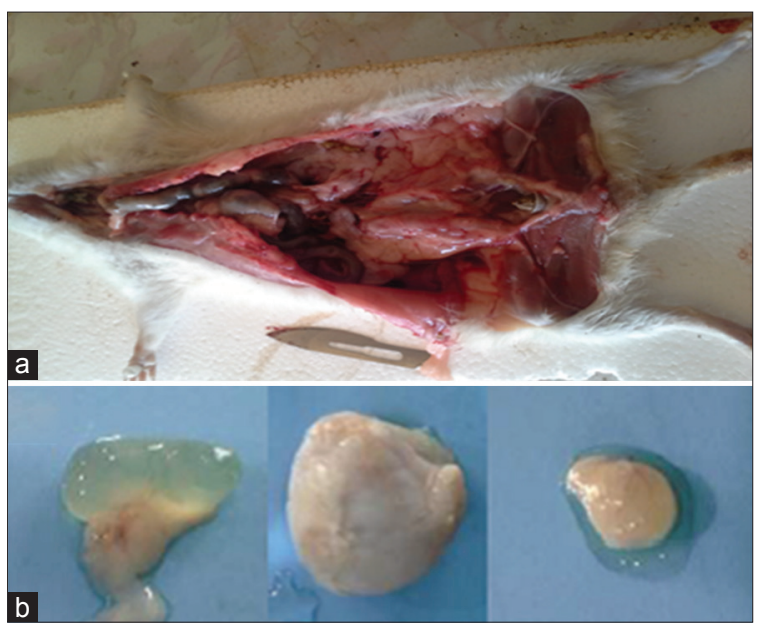

Fig. 5: The sacrificing and complete autopsies of animal appeared fat aggregate in abdomenal cavity (a), and (b) the tumor mass formation in DMBA-control group, including from the lift to right fat cysts, connective mass tissues and mammary gland carcinoma act as an antioxidant both by binding to the radicals and by directly scavenging oxidizing species. It, therefore, inhibits lipid peroxidation. Glucose also acts as a scavenger of hydroxyl radicals [89]. The levels of all these antioxidants were found to be decreased with an increase in lipid peroxidation in plasma of rats exposed either to stress alone or DMBA alone.

\section{CONCLUSION}

The date palm P. dactylifera pits in addition to fruit had protective effects against DMBA-induced mammary cancer in the initiation, promotion, and progression stages of DMBA-induced mammary carcinogenesis. These effects are required further research to clarify the possible mechanisms that might have contributed to the preventive effect of this fruit against mammary cancer.

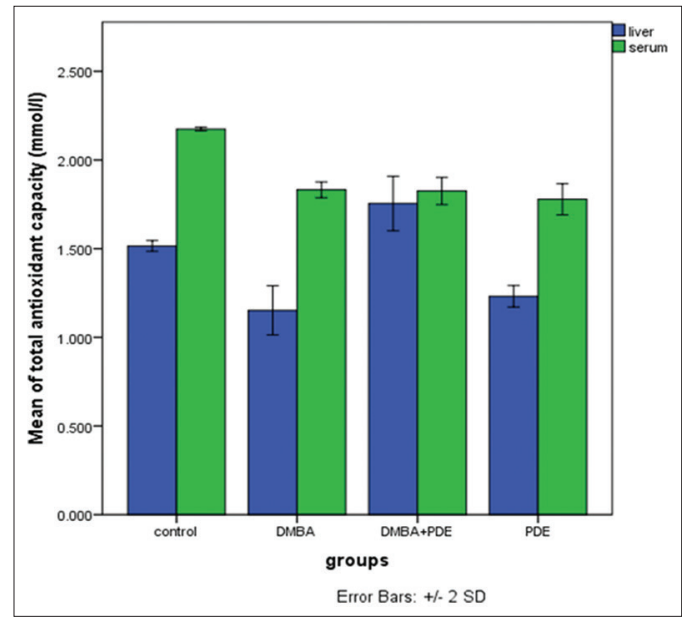

Fig. 6: The total antioxidant capacity of serum and livers of experimental rat groups treated with 7,12-dimethylbenz(a) anthracene (DMBA) carcinogen and the partially purified phenolics of date pits. Values are expressed as mean \pm standard deviation $(n=6)$. Statistical significance was done by one way ANOVA followed by least significant difference. The mean difference is significant at the 0.05 level $(p<0.000-0.001)$ for DMBA and DMBA+partially purified phenolic extract of Phoenix dactylifera pits groups compared with control group of liver total antioxidant capacity and they were not the significance of serum total antioxidant status. Dunnett t-tests (2-sided) treat one group as a control, and compare all other groups against it

Table 4: Effect of P. dactylifera extract on Hematological parameters in control and experimental rats

\begin{tabular}{|c|c|c|c|c|c|}
\hline $\begin{array}{l}\text { Blood } \\
\text { Parameters }\end{array}$ & $\begin{array}{l}\text { Group I } \\
\text { Control }\end{array}$ & $\begin{array}{l}\text { Group II } \\
\text { DMBA control }\end{array}$ & $\begin{array}{l}\text { Group III } \\
\text { DMBA+PDE }\end{array}$ & $\begin{array}{l}\text { Group IV } \\
\text { PDE control }\end{array}$ & Lower-upper limits \\
\hline $\mathrm{WBC}\left(10^{3} / \mu \mathrm{l}\right)$ & $9.70 \pm 2.79$ & $6.12 \pm 2.39$ & $7.64 \pm 4.01$ & $8.50 \pm 3.08$ & $4.00-12.00$ \\
\hline LYM \% & $41.90 \pm 9.02$ & $77.08 \pm 6.85^{*}$ & $58.51 \pm 9.47 *$ & $38.00 \pm 9.89$ & $25.00-50.00$ \\
\hline MON \% & $7.70 \pm 2.54$ & $10.20 \pm 1.06$ & $15.73 \pm 2.93 *$ & $6.83 \pm 2.63$ & $2.00-10.00$ \\
\hline GRA \% & $65.90 \pm 11.58$ & $13.00 \pm 5.66^{*}$ & $25.89 \pm 7.13^{*}$ & $61.67 \pm 12.90$ & $50.00-80.00$ \\
\hline НCT \% & $45.70 \pm 7.25$ & $33.70 \pm 0.62 *$ & $32.90 \pm 1.67 *$ & $44.50 \pm 9.24$ & $35.00-55.00$ \\
\hline RDW \% & $13.80 \pm 2.20$ & $16.65 \pm 1.07^{*}$ & $17.16 \pm 0.99 *$ & $12.83 \pm 2.31$ & $10.00-16.00$ \\
\hline $\mathrm{HGB}(\mathrm{g} / \mathrm{dl})$ & $14.15 \pm 2.66$ & $10.82 \pm 0.07^{*}$ & $10.68 \pm 0.56^{*}$ & $13.08 \pm 2.69$ & $11.00-17.00$ \\
\hline $\operatorname{MCV}\left(\mu \mathrm{M}^{3}\right)$ & $90.70 \pm 9.29$ & $58.72 \pm 1.29 *$ & $61.88 \pm 8.93 *$ & $87.17 \pm 9.26$ & $80.00-100.00$ \\
\hline $\mathrm{MCH}(\mathrm{pg})$ & $30.80 \pm 2.93$ & $18.83 \pm 0.18^{*}$ & $20.11 \pm 2.82 *$ & $29.67 \pm 3.26$ & $26.00-34.00$ \\
\hline $\operatorname{MCHC}(\mathrm{g} / \mathrm{dl})$ & $33.10 \pm 1.77$ & $32.03 \pm 0.33$ & $32.49 \pm 0.25$ & $32.92 \pm 1.85$ & $31.00-35.50$ \\
\hline $\operatorname{PLT}\left(10^{3} / \mu \mathrm{l}\right)$ & $315.00 \pm 96.75$ & $787.33 \pm 59.90^{*}$ & $604.67 \pm 65.72^{*}$ & $283.33 \pm 112.72$ & $150.00-400.00$ \\
\hline $\operatorname{MPV}\left(\mu \mathrm{M}^{3}\right)$ & $9.40 \pm 1.59$ & $5.99 \pm 0.13^{*}$ & $5.90 \pm 0.39 *$ & $8.92 \pm 1.74$ & $7.00-11.00$ \\
\hline
\end{tabular}

Values are expressed as mean \pm SD $(n=6)$. Statistical significance was performed by one-way ANOVA followed by LSD. ${ }^{*}$ The mean difference is significant at the 0.05 level ( $\mathrm{p}<0.01-0.001)$. Dunnett t-tests (2-sided) treat one group as a control, and compare all other groups against it. P. dactylifera: Phoenix dactylifera, LYM: Lymphocyte, PDE: P. dactylifera extract, DMBA: Carcinogenic gent 7.12-dimethylbenz[a] anthracene, WBC: White blood cells, RBC: Red blood cells, HGB: Hemoglobin, HCT: Hematocrit, MCV: Mean corpuscular volume, MCH: Mean corpuscular hemoglobin, MCHC: Mean corpuscular hemoglobin concentration, RDW: Red cell distribution width, PLT: Platelets, MPV: Mean platelet volume, MON: Monocyte, GRA: Granulocyte 


\section{ACKNOWLEDGMENT}

The authors are thankful to Pioneer Projects Department, Research and Development Directorate, Ministry of Higher Education and Scientific Research, Iraq, for funding this research which was done at the Laboratory of Biotechnology and Genetic Engineering, Biology Department, College of Science, University of Babylon, Iraq.

\section{REFERENCES}

1. Tang ZX, Shi LE, Aleid SM. Date fruit: Chemical composition, nutritional and medicinal values, products. J Sci Food Agric 2013;93(10):2351-61.

2. El-Far AH, Shaheen HM, Abdel-Daim MM, Al-Jaouni SK, Mousa SA. Date palm (Phoenix dactylifera): Production and remedy food. Curr Trends Nutracetical 2016;1(2):1-10.

3. Marzouk HA, Kassem HA. Improving fruit quality, nutritional value and yield of Zaghloul dates by the application of organic and/or mineral fertilizers. Sci Hortic 2011;127:249-54

4. Manickavasagan A, Essa MM, Sukumar E. Dates: Production, Processing, Food, and Medicinal Values. Boca Raton: CRC Press; 2012. p. 415

5. Ishurd O, Kennedy JF. The anti-cancer activity of polysaccharide prepared from Libyan dates (Phoenix dactylifera L.). Carbohydr Polym 2005;59:531-5.

6. Elias M, Aviram M. Effect of date (Phoenix dactylifera $\mathrm{L}$ ), madjool or hallawi variety) consumption by healthy subjects on serum glucose and lipid levels and on serum oxidative status: A pilot study. J Agric Food Chem 2009;57:8010-7.

7. Sharma R, Chandan G, Chahal A, Saini RV. Antioxidant and anticancer activity of methanolic extract from Stephania elegans. Int J Pharm Pharm Sci 2017:9:245-9.

8. Chaira N, Mrabet A, Ferchichi A. Evaluation of antioxidant activity, phenolics, sugar and mineral contents in date palm fruits. J Food Biochem 2009;33:390-403.

9. Vyawahare $\mathrm{N}$, Pujari $\mathrm{R}$, Khsirsagar A, Ingawale D, Patil M, Kagathara V. Phoenix dactylifera: An update of its inedegenous uses, phyto2008;150:3.and pharmacology. Internet J Pharmacol 2009;7. DOI: $10.5580 / 164 b$.

10. Kim D, Jeond S, Lee C. Antioxidant capacity of phenolic phytochemicals from various cultivars of plams. Food Chem 2003;81:321-6.

11. El-Hassni M, J'Aiti F, Dihazi A, Barka EA, Daayf F, El-Hadrami I. Enhancement of defense responses against bayoud disease by treatment of date palm seedlings with a hypoaggressive Fusarium oxysporum isolate. J Phytopathol 2004;152:182-9.

12. J'Aiti F, Verdeil JL, El-Hadrami I. Effect of jasmonic acid on the induction of polyphenoloxidase and peroxidase activities in relation to date palm resistance against Fusarium oxysporum f. sp. Albedinis. Physiol Mol Plant Pathol 2009;74:84-90

13. EL-Hadrami A, AL-Khayri JM. Socioeconomic and traditional importance of date palm. Emirates J Food Agric 2012;24:371-85.

14. Boots AW, Haenen GR, Bast A. Health effects of quercetin: From antioxidant to nutraceutical. Eur J Pharmacol 2008;585(2-3):325-37.

15. Lau T. A healthy way to live: The occurance, bioactivity, biosynthesis, and synthesis of kaempferol. Chemistry 2008;150. P. 3

16. Yoshida T, Konishi M, Horinaka M, Yasuda T, Goda AE, Taniguchi H, et al. Kaempferol sensitizes colon cancer cells to TRAIL-induced apoptosis. Biochem Biophys Res Commun 2008;375(1):129-33.

17. Calderon-Montano JM, Burgos-Moron E, Perez-Guerrero C, Lopez-Lazaro M. A review on the dietary flavonoid kaempferol. Mini Rev Med Chem 2011;11:298-44.

18. Biglari F. Assessment of Antioxidant Potential of Date (Phoenix dactylifera L.) Fruits from Iran, Effect of Cold Storage and Addition to Minced Chicken Meat. MSc Thesis, University Sains Malaysia; 2009.

19. Haris M, Mahmood R, Rahman H, Rahman N. In vitro cytotoxic activity of Clerodendrum infortunatum L. Against T47D, PC-3, A549 and HCT-116 human cancer cell lines and its phytochemical screening. Int J Pharm Pharm Sci 2016;8:439-44.

20. El-Aaser A, E'l-Merzabani M, Abudedair F. Etiology of human breast cancer. In: Abdel-Meguid L, Omar S, editors. Breast Cancer: A Comprehensive Approach. Egypt: Cairo Medical Syndicate; 1982. p. $25-46$

21. Heldring N, Pike A, Andersson S, Matthews J, Cheng G, Hartman J, et al. Estrogen receptors: How do they signal and what are their targets. Physiol Rev 2007;87(3):905-31.

22. Al-Sayyed HF, Takruri HR, Shomaf MS, Al-Saleh AR. The effect of date palm fruit (Phoenix dactylifera $\mathrm{L}$.) on the hormone 17- $\beta$-estradiol in 7,12-dimethylbenz(a)anthracene-induced mammary cancer in rats. Mediterr J Nutr Metab 2014; 7:5-10.

23. Poirier LA. Stages in carcinogenesis: Alteration by diet. Am J Clin Nutr 1987;45 1 Suppl:185-91

24. Pavia DL, Lampman GM, Kriz GS, Vyvyan JR. Microscale and Macroscale Techniques in the Organic Laboratory. USA: Brooks/Cole; 2002.

25. Tomas-Barberan FA, Ferreres F. Analytical methods of flavonols and flavones. In: Xu Z, Howard LR, editors. Analysis of Antioxidant-Rich Phytochamicals. $1^{\text {st }}$ ed. UK: Wiley-Blackwell, Wiley \& Sons, Ltd., Publication; 2012. p. 207-46.

26. Xu Z. Analysis method of phenolic acids. In: Xu Z, Howard LR, editors. Analysis of Antioxidant-Rich Phytochamicals. $1^{\text {st }}$ ed. UK: Wiley-Blackwell, Wiley \& Sons, Ltd., Publication; 2012. p. 69-104.

27. Chaves TP, Santana CP, Véras G, Brandão DO, Felismino DC, Medeiros AC, et al. Seasonal variation in the production of secondary metabolites and antimicrobial activity of two plant species used in Brazilian traditional medicine. Afr J Biotechnol 2013;12:847-53.

28. Apak R, Guclu K, Ozyurek M, Karademir SE. Novel total antioxidant capacity index for dietary polyphenols and vitamins $\mathrm{C}$ and $\mathrm{E}$, using their cupric ion reducing capability in the presence of neocuproine: CUPRAC method. J Agric Food Chem 2004;52:7970-81.

29. Freshney RI. Culture of Animal Cell. $6^{\text {th }}$ ed. New York: Wily-Liss; 2010.

30. Liu CP, Tsai WJ, Lin YL, Liao JF, Chen CF, Kuo YC. The extracts from Nelumbo Nucifera suppress cell cycle progression, cytokine genes expression, and cell proliferation in human peripheral blood mononuclear cells. Life Sci 2004;75(6):699-716.

31. Barros AC, Muranaka EN, Mori LJ, Pelizon CH, Iriya K, Giocondo G, et al. Induction of experimental mammary carcinogenesis in rats with 7,12-dimethylbenz(a)anthracene. Rev Hosp Clin Fac Med Sao Paulo 2004;59(5):257-61.

32. Weesner FM. General Zoological Microtechniques. Calcutta: Scientific Book Agency; 1968

33. Newsholme EA. Carbohydrate metabolism in vivo: Regulation of the blood glucose level. Clin Endocrinol Metab 1976;5(3):543-78.

34. Moron MS, Depierre JW, Mannervik B. Levels of glutathione, glutathione reductase and glutathione S-transferase activities in rat lung and liver. Biochim Biophys Acta 1979;582(1):67-78.

35. Cai Y, Luo Q, Sun M, Corke H. Antioxidant activity and phenolic compounds of 112 traditional Chinese medicinal plants associated with anticancer. Life Sci 2004;74(17):2157-84

36. Giovanelli G, Brambilla A, Rizzolo A, Sinelli N. Effects of blanching pre-treatment and sugar composition of the osmotic solution on physico-chemical, morphological and antioxidant characteristics of osmodehydrated blueberries. Food Res Int 2012;49:263-71.

37. Siddiq M, Ahmed J, Lobo MG, Ozadali F. Tropical and subtropical fruits. Postharvest Physiology, Processing and Packaging. Ames, Iowa: Wiley-Blackwell; 2012. p. 664

38. Al-Farsi M, Alasalvar C, Al-Abid M, Al-Shoaily K, Al-Amry M, Al-Rawahy F. Compositional and functional characteristics of dates, syrups, and their by-products. Food Chem 2007;104:943-7.

39. Rivero-Pérez MD, Muñiz P, Gonzalez-Sanjosé ML. Antioxidant profile of red wines evaluated by total antioxidant capacity, scavenger activity, and biomarkers of oxidative stress methodologies. J Agric Food Chem 2007;55(14):5476-83.

40. Al-Farsi MA, Lee CY. Optimization of phenolics and dietary fibre extraction from date seeds. Food Chem 2008;108(3):977-85.

41. Wu X, Beecher GR, Holden JM, Haytowitz DB, Gebhardt SE, Prior RL Lipophilic and hydrophilic antioxidant capacities of common foods in the United States. J Agric Food Chem 2004;52(12):4026-37.

42. Al-Farsi M, Alasalvar C, Morris A, Baron M, Shahidi F. Comparison of antioxidant activity, anthocyanins, carotenoids, and phenolics of three native fresh and sun-dried date (Phoenix dactylifera L.) varieties grown in Oman. J Agric Food Chem 2005;53(19):7592-9.

43. Saafi EB, El-Arem A, Issaoui M, Hammami M, Achour L. Phenolic content and antioxidant activity of four date palm (Phoenix dactylifera L.) fruit varieties grown in Tunisia. Int J Food Sci Technol 2009:44:2314-9.

44. Ammar NM, El-Kassem LT, EL-Sayed NH, Calabria LM, Mabry TJ. Flavonoid constituents and antimicrobial activity of date (Phoenix dactylifera L.) seeds growing in Egypt. Med Aromat Plant Sci Biotechnol 2009;3(1):1-5.

45. Nijveldt RJ, van Nood E, van Hoorn DE, Boelens PG, van Norren K, van Leeuwen PA. Flavonoids: A review of probable mechanisms of action and potential applications. Am J Clin Nutr 2001;74(4):418-25. 
46. Sandhar HK, Kumar B, Prasher S, Tiwari P, Salhan M, Sharma P. A review of phytochemistry and pharmacology of flavonoids. Int Pharm Sci 2011;1(1):25-41.

47. Messaoudi R, Abbeddou S, Mansouri A, Calokerinos AC, Kefalas P. Phenolic profile and antioxidant activity of date-pits of seven Algerian date palm fruit varieties. Int J Food Prop 2013;16:1037-47.

48. Abou-Elella FF, Mourad R. Anticancer and anti-oxidant potentials of ethanolic extracts of Phoenix dactylifera, Musa acuminata and Cucurbita maxima. Res J Pharm Biol Chem Sci 2015;6(1):710-20.

49. AL-Daody AC, AL-Hyaly AM, AL-Soultany AA. Chromatographic identification of some flavonoids compounds from 'Cyperus rotundas' growing in Iraq. Tikrit J Pure Sci 2010;15(1):218-22.

50. Ćetković GS, Đilas SM, Čanadanović-Brunet JM, Tumbas VT. Thinlayer chromatography analysis and scavenginig activity of marigold (Calendula officinalis L.) extracts. APTEFF 2003;34:1-148.

51. Hong YJ, Tomas-Barberan FA, Kader AA, Mitchell AE. The flavonoid glycosides and procyanidin composition of Deglet Noor dates (Phoenix dactylifera). J Agric Food Chem 2006;54(6):2405-11.

52. Hussein AM, El-Mousalamy AM, Hussein SA, Mahmoud SA. Effects of palm dates (Phoenix dactylifera $\mathrm{L}$ ) extracts on hepatic dysfunction Type 2 diabetic rat model. World J Pharm Pharm Sci 2015;4(7):62-79.

53. Robbins RJ, Bean SR. Development of a quantitative high-performance liquid chromatography-photodiode array detection measurement system for phenolic acids. J Chromatogr A 2004;1038(1-2):97-105.

54. Pavia DL, Lampman GM, Kriz GS, Vyvyan JR. Introduction to Spectroscopy. USA: Brooks/Cole; 2009.

55. Jamahseri NF, Rodhi MN, Zulkarnain NH, Husain NC, Masruddin AF. FTIR analysis of phenolic compound as pancreatic lipase inhibitor from inculated Aquilaria malaccensis. Malays J Anal Sci 2014;18(3):683-9.

56. Petroski JM, Valente CD, Kelson EP, Collins S. FTIR spectroscopy of flavonols in argon and methanol/argon matrixes at $10 \mathrm{~K}$. Reexamination of the carbonyl stretch frequency of 3-Hydroxyflavone. J Phys Chem A 2002;106:11714-8

57. Sharaf S, Higazy A, Hebeish A. Propolis induced antibacterial activity and other technical properties of cotton textiles. Int J Biol Macromol 2013:59:408-16

58. Isoniemi E, Khriachtchev L, Lundell $\mathrm{J}$, Rasanen $\mathrm{M}$. $\mathrm{HSO}_{2}$ isomers in rare-gas solids. Phys Chem Chem Phys 2002: 4 (9): 1549. Doi: 10.1039/b110109a.

59. Andrews L, Wang X. Infrared spectra of the novel Si2H2 and Si2H4 species and the SiH1,2,3 intermediates in solid Neon, Argon, and Deuterium. J Phys Chem A 2002;106(34):7696 -702. Doi: 10.1021/ jp0204814.

60. Lingegowda DC, Kumar JK, Prasad AG, Zarei M, Gopal S. The spectroscopic studies on Cleome gynandra-comparative analysis of functional group before and after extraction. Rom J Biophys 2012;22(34):137-43.

61. Mot A, Silaghi-Dumitrescu R, Sarbu C. Rapid and effective evaluation of the antioxidant capacity of propolis extracts using DPPH bleaching kinetic profiles, FT-IR and UV-vis spectroscopic data. J Food Compos Anal 2011;24(4-5):516-22.

62. Silverstein R, Webster F. Spectrometric Identification of Organic Compounds. $6^{\text {th }}$ ed. London, UK: John Wiley and Sons, Inc. Publishers; 1997.

63. Maier G, Preiss T, Reisenauer HP, Hess BA Jr, Schaad LJ. Small rings. Part 81. Chlorinated cyclopropenylidenes, vinylidenecarbenes, and propargylenes: Identification by matrix isolation spectroscopy. J Am Chem Soc 1994;116(5). DOI: 10.1021/JA00084A047.

64. Pandit NT, Patravale VB. Design and optimization of a novel method for extraction of genistein. Indian J Pharm Sci 2011;73(2):184-92.

65. Rieder CR, Parsons RB, Fitch NJ, Williams AC, Ramsden DB. Human brain cytochrome P450 1B1: Immunohistochemical localization in human temporal lobe and induction by dimethylbenz(a) anthracene in astrocytoma cell line (MOG-G-CCM). Neurosci Lett 2000;278(3):177-80.

66. Cavalieri E, Roth R, Rogan E. Mechanisms of tumor initiation by polycyclic aromatic hydrocarbons. Carcinogenesis 1978;3:273-87.

67. Choi EJ. Antioxidative effects of hesperetin against 7,12 dimethylbenz (a)anthracene-induced oxidative stress in mice. Life Sci 2008;82:1059-64.
68. Benakanakere I, Besch-Williford C, Carroll CE, Hyder SM. Synthetic progestins deferentially promote or prevent 7,12-DMBA induced mammary tumors in sprague-dawley rats. Cancer Prev Res 2010;3:1157-67.

69. Vinothini G, Murugan RS, Nagini S. Evaluation of molecular markers in a rat model of mammary carcinogenesis. Oncol Res 2009;17(10):483-93

70. Fang J, Seki T, Maeda H. Therapeutic strategies by modulating oxygen stress in cancer and inflammation. Adv Drug Deliv Rev 2009;61:290-302.

71. Thompson HJ, Singh M. Rat models of premalignant breast disease. J Mammary Gland Biol Neoplasia 2000;5(4):409-20.

72. Desai GV, Caseiano D, Feuers JR, Aidoo A. Activity profile of glutathione-dependent enzymes and respiratory chain complexes in rats supplemented with antioxidant and trated with carcinogens. Arch Biochem Biophys 2001;394:255-64.

73. el-Mofty MM, Abdelmeguid NE, Sadek IA, Essawy AE, Aleem EA. Induction of leukaemia in chloramphenicol-treated toads. East Mediterr Health J 2000;6(5-6):1026-34.

74. Grubbs CJ, Juliana MM, Hill DL, Whitaker LM. Suppression by pregnancy of chemically induced preneoplastic cells of the rat mammary gland. Anticancer Res 1986;6(6):1395-400

75. Mathivadhani P, Shanthi P, Sachdanandam P. Effect of Semecarpus anacardium Linn. Nut extract on mammary and hepatic expression of xenobiotic enzymes in DMBA-induced mammary carcinoma. Environ Toxicol Pharmacol 2007;23:328-34.

76. Devlin TM. Textbook of Biochemistry: With Clinical Correlations. $4^{\text {th }}$ ed. New York: Wiley \& Sons; 1997. p. 553.

77. Ammar NM, Al-Okbi SY, Mohamed DA, Abou El-Kassem LT. Antioxidant and estrogen like activity of the seed of Phoenix dactylifera L. Palm growing in Egyptian oases. Rep Opin 2009;1(3):1-8

78. Mugesh G, du Mont WW, Sies H. Chemistry of biologically important synthetic organoselenium compounds. Chem Rev 2001;101(7):2125-79.

79. Das RK, Ghosh S, Sengupta A, Das S, Bhattacharya S. Inhibition of DMBA/croton oil-induced two-stage mouse skin carcinogenesis by diphenylmethyl selenocyanate. Eur J Cancer Prev 2004;13(5):411-7.

80. Bhuvaneswari V, Velmurugan B, Abraham SK, Nagini S. Tomato and garlic by gavage modulate 7,12-dimethylbenz[a]anthracene-induced genotoxicity and oxidative stress in mice. Braz J Med Biol Res 2004;37(7):1029-34.

81. Takemura H, Sakakibara H, Yamazaki S, Shimoi K. Breast cancer and flavonoids-a role in prevention. Curr Pharm Des 2013;19(34):6125-32.

82. Morrison VM, Burnett AK, Forrester LM, Wolf CR, Craft JA. The contribution of specific cytochromes P-450 in the metabolism of 7,12-dimethylbenz[a] anthracene in rat and human liver microsomal membranes. Chem Biol Interact 1991;79(2):179-96.

83. Middleton E Jr, Kandaswami C, Theoharides TC. The effects of plant flavonoids on mammalian cells: Implications for inflammation, heart disease, and cancer. Pharmacol Rev 2000;52(4):673-751.

84. Schnitz AR, O'Connor JM. In vivo DNA/RNA adduction of 7,12-dimethyl-benz(a)anthracene (DMBA) and benzo(a)pyrene (BaP) in the liver of rainbow trout (Oncorhynchus mykiss). J Envion Pathol Toxicol Oncol 1992;11:229-33.

85. Perez Gutierrez RM, Anaya Sosa I, Hoyo Vadillo C, Victoria TC. Effect of flavonoids from Prosthechea michuacana on carbon tetrachloride induced acute hepatotoxicity in mice. Pharm Biol 2011;49(11):1121-7.

86. Muqbil I, Banu N. Enhancement of pro-oxidant effect of 7,12-dimethylbenz (a) anthracene (DMBA) in rats by pre-exposure to restraint stress. Cancer Lett 2006;240(2):213-20.

87. Horoz M, Bolukbas C, Bolukbas FF, Sabuncu T, Aslan M, Sarifakiogullari S, et al. Measurement of the total antioxidant response using a novel automated method in subjects with nonalcoholic steatohepatitis. BMC Gastroenterol 2005, 5:35. http://www. biomedcentral.com/1471-230X/5/35.

88. Al-Athar AM. The influence of dietary grape seed oil on DMBAinduced liver enzymes disturbances in the frog, Rana ridibunda. Pak J Nutr 2004;5:304-9.

89. Halliwell B, Gutteridge JM. The antioxidants of human extracellular fluids. Arch Biochem Biophys 1990;280(1):1-8. 